\title{
Does Exports Promote the Economic Growth of China? A Long-Run View Point
}

\author{
Qiang Jiang ${ }^{1}$ \\ ${ }^{1}$ School of Economics, Shanghai University, Shanghai, China \\ Correspondence: Qiang Jiang, PhD, School of Economics, Shanghai University, Shanghai, China.
}

Received: January 10, 2017

Accepted: February 9, 2017

Online Published: February 28, 2017

doi:10.5430/ijfr.v8n2p64

URL: http://dx.doi.org/10.5430/ijfr.v8n2p64

\begin{abstract}
This paper empirically studied the influence of exports on long-run economic growth of China at the present stage, using the 2002-2012 panel data of provinces. Results showed that the exports hinder the long-run economic growth of China. Based on the theory of technology and resource, We researched the influencing mechanism of exports on long-run economic growth from three aspects: the influence of exports on total factor productivity, the influence of exports on human capital and the influence of exports on consumption of energy and mineral resources. The empirical study results showed that although exports enhanced the standard of human capital, exports depressed the progress of total factor productivity, and consumed enormous energy and mineral resources. So the total effection is exports hinder the long-run economic growth of our country at present stage.
\end{abstract}

Keywords: exports, long-run economic growth, total factor productivity, human capital, the consumption of energy and mineral resources

\section{Introduction}

If we survey the welfare effection of exports, exports induce more production within global scope through developing comparative advantage of every country, but some countries get more benefits and others get less. Because of the difference of price elasticity among different commodity and the division of labor in value chain of global producing system, developed countries with high-tech will grasp the core production process and developing countries with low-tech will carry on processing trade relying on abundant labor. So on the international trade among developing countries and developed countries, developing countries take the role of "employee". The famous economist, Prebisch, have pointed out this problem in the last century that developing countries faced an unfair competition on the international division of labor using the theory of "Center-periphery". Developed countries export commodities with high-tech relying on the advantage of technology and the control of value chain, while developing countries just use the advantage of low-price labor and other low-end production factors to take the production process controled by multinational companies in developed countries, and exports in developing countries mainly are processing trade. This model of international division of labor is and always will to be more strengthen, with the time flys, the sustainable developmen of developing countries will be threatened by this model of international division of labor.

The gross exports of China had reached to 2.21 trillions of dollars, and ranking first on the world. This situation makes us optimistic from the gross amount, but the trade structure catches our concern that our major trade style is processing trade. On the initial stage of Chinese economic reform, processing trade meeted the advantage of China that deficiency capital and plentiful labor. But nowadays, China has turned to be a country filled with enormous capital and demographic dividend will to be disappear gradually. Although the production factors structure have changed so much, the export structure still keep on the initial step of processing trade. Does the exports, especially the processing trade, promote the economic growth of China, likewise as before. Many famous scholars take the view that the successful economic performance of China is the duplicate of the Four Asian Tigers' economic model. But the difference existing among China and the Four Asian Tigers is they have finished the changement of economic development model from processing trade to R\&D and high-end manufacturing, while China still rest on processing trade. With the nature resource depletion constantly, increasing environmental pollution and rising labor costs, even taking the demand pull into consideration, does the exports promote the long-run economic growth? Previous studies were mainly taken based on the causality between exports and GDP, and never distinct the long-run 
economic growth and short-run. This research method based on time-series data cann't observe the deeply influence effection of exports on economic growth. This paper will change the research method before, and empirically study the influence of export on ecnomic growth of China, using new data and new influencing mechanism. The next parts are arranged as follows: part two is literature review; part three is the empirical study; part four is the empirical study summary; last part is the conclusions and policy recommendations.

\section{Literature Review}

As to the casuality of exports and GDP, although majority economists approve the view that "Export-Led Growth", this problem did not reach a consensus. Papers which support the hypothesis of "ELG"(Export-Led Growth) mainly base on the technology spillovers from export sector to non-export sector. The style of spillover mainly manifestes in the following points: more effective way of management spills through vertical integration; production technology spillover; scale effect due to the global market demand; the accumulation of human capital and physical capital; the effect of "Learning By Doing". Tyler (1980) tested the hypothesis of "ELG" using the 1960-1977 data of 55developing countries; Feder (1982) certified the hypothesis of "ELG" using the 1964-1973 data of major developing countries and developed countries; Ram (1985) approved the idea of "ELG" after empirical study on 73 less-developing countries, and after two years, Ram (1987) used 88 less developing countries to approve it again; In order to overcome the endogeneity problem, Frankel \& Romer (1999) used national geographic features as instrument variable to test the causality between exports and economic growth, they found the path that exports led growth mainly based on the physical capital accumulation; Medina-Smith (2001) tested the theory of "ELG" using 1950-1970 time-series data of Republic of Costa Rica, and found it is correct about this theory; Keong et al. (2005) tested this theory using 1960-2001 time-series data of Malaysia and approved it again; Parida \& Sahoo (2007) used the 1980-2002 panel data of four countries, including India, Pakistan, Bangladesh and Sri Lanka, after excluding exports from GDP, empirical study results showed that exports promoted this areas' economic growth.

But some other economists never found the evidence to approve this theory of "ELG", Ahmad and Kwan (1991) took emiprical study on the 1976-1990 data of association of southeast asian nations, they found no evidence to approve this theory of "ELG" except Singapore; Alam (2003) used 1959-1990 time-series data of Mexico and 1955-1990 time-series data of Brazil to test this problem, results can not support the theory; Abu-Qarn \& Suleiman (2001) used time-series data of 9 countries including Middle Eastern and North African to test this theory, results showed that just Algeria and Sudan support it; Akbar \& Fatima (2003) rejectted the theory after using 1975-1998 seasonal time-series of Pakistan to test it; Jung \& Marshall (1985) tested it using 37 developing countries' data, results showed that they keep skeptical about the theory; Meanwhile, parts of research showed there is no relationship between exports and economic growth (Muhammad \& Sampath, 1997).

Specific to the detailed research, because of the different samples existing on countries and time, the research results showed divergence to some extent. As to the theory of "ELG", we take the point that "ELG" will be right under a certain conditions. Kilavuz \& Topcu (2012) tested "ELG" hypothesis using the 1998-2006 data of 22 developing countries, results showed that "ELG" hypothesis must based on the commodities structure of export, and exports with high-tech goods will promote the economic growth of developing countries. According to the commodity supply and demand elasticity, they also draw a conclusion that exports could promote the economic growth of developed countries much more. Lim et al. (2011) took research about the "ELG" hypothesis on newly industrialized countries in southeast Asia, results showed that the relationship between exports and economic growth is not linear, the theory of "ELG" suits majority countries. Rivera-Batiz \& Romer (1991) found that when the trade happen among countries which have the similar technology and factor endowment, "ELG" hypothesis can be satisfied. According to the research of Young (1991), developed countries concentrate on the high-tech commodities production and export, while developing countries concentrate on the low-tech commodities production and export. Within his theory, there is a hypothesis: high-tech commodities will be accompanied by more "learning by doing" effect, while low-tech commodities just consume countless production factors. So developing countries conn't acquire more, while exports can promote the economic growth of developed countries. Chuang (1998) expressed the influence of exports on economic growth using a model through the effect of "learning by doing", and results showed that the influence of exports on economic growth was mainly based on the commodity quality and technology, the export destination. Lucas (1988) also pointed out that when a country concentrates on exports of commodities filled with high-tech, the theory of "ELG" can be worked. Cuaresma \& Worz (2005) tested the tehory of "ELG", using 1981-1997 panel data of 45 developing and developed countries, results showed that manufactured goods with high-tech can prompt the economic growth of one country remarkablely, while commodities with low- tech are not obvious. Boltho (1996) tested the time distribution of the "ELG" theory about Japan, with the time-series data dividing into three parts. The data of 1952-1973 supports the hypothesis of "ELG"; The data of 1913-1937 and 1973-1990 had no evidence to 
certify this theory. Herzer et al. (2005) used 1960-2000 time-series data of Chile to test the theory of "ELG", results showed that just manufacturing exports support the "ELG" hypothesis. The research method of these papers are mainly based on the co-integration analysis and granger causality test between exports and GDP. In our opinions, This method cann't reflect the full influence of exports on economic growth. Firstly, exports and economic growth can be influenced mutually, and it's to be a problem of endogeneity; Secondly, the influence of exports on the long-run economic growth maybe have lag phase; Lastly, the influencing mechanism of exports on long-run economic growth couldn't be reflected by those research method, such as the influence of exports on human capitcal, on the accumulation of material capital and technology spillover. Most economists carried out the research of exports on economic growth mainly based on the hypothesis of "ELG", but the reality that Africa and Latin America's economic performance is not as well as the "ELG" hypothesis. Some development economists have made a criticism that there is no facts to support the hypothesis when they apply the hypothesis on some developing countries. Developing countries always turn to be the supply source of energy and mineral resources needed by developed countries. As stated above, China outputs large numbers of commodity through exports which always are the primary goods not filled with high-tech. After the policy of opening and reform, China had began to brought into the international product system dominanted by the transnational corporation of developed countries. Although exports promote the economic growth in short-run, the long-run economic growth of China cann't be guaranteed. This paper will research the long-run relationship between exports and economic growth based on the the reality of China that exports turn to be increasing more and more, but economic growth turn to be slower than before.

\section{The Influence of Exports on Long-run Economic Growth Factor}

Different from short-term economic growth, long-run economic growth is mainly based on endogenous economic growth. Badinger \& Tondl (2002) pointed out that long-run economic growth depend on endogenous economic growth when they made research of the 1990s' economic growth of European area. Meanwhile, they also view that physical capital accumulation and human capital accumulation are the main channels of endogenous economic growth. In addition to those two channels, innovation and technology spillover is another important aspect which could prompt economic growth. When we specific on the long-run economic growth, classical economists generally aggre the Say's Law which express a theory that long-run economic growth depend on supply capacity, and market supply depend on the quality and quantity of labors, the numbers of physical capital and financial capital, the efficiency of production organization and the capacity of technology innovation. So we also summarize the influence factors of exports on long-run economic growth as follows: 1. The total factor productivity, which includes promote and hinder roles. Exports can promote the TFP through technology spillover and the enhancement of efficiency of resource allocation, while it also hinde the TFP when one country over rely on the exports of low added value commodity. 2. The enhancement of human capital. 3. The accumulation of physical capital. 4. The consumption of natural resource and energy source which are non-renewable. 5. The environment pollution and ecological damage. After the work taken by Howitt \& Aghion (1998) that they incude the physical capital into the endogenous economic growth, they found that physical capital is the decisive factor of economic growth. Experienced the openning and reforming policy, China have enormous foreign currency reserve and completed infrastractural facilities, meanwhile, the decreasing marginal returns of financial capital and higher labor prices also reflect that China have turned to be a country which never keep a situation of capital scarcity. So we will never take empirical study on the influence of exports on the accumulation of physical capital. What's more, the influence of exports on environment also cann't be measured accurately. So we lay the important points of the influence of export on the long-run economic growth on technology progress, the accumulation of human capital and the consumption of natural resource and energy source which are non-renewable. Data covers the provincial panel data from 2002 to 2012 . We chose this period because the government leaders never changed among this period which can avoid the policy fluctuation. The next reason we chose this period is because the export volume was rising rapidly, the growth rate of exports is more than GDP', so we think this poriod could reflect the essential feature of exports which will be benefical to our research.

\subsection{The Influence of Exports on Technology Progress of China}

\section{(1). Model Specification}

Since the 1990s, the theory of endogenous economic growth which represented by Romer (1990), Grossman \& Helpman (1991) and Aghion \& Howitt (1992) attached great importance to research \& development which will prompt the standard of technology progress. The accumulation of innovation and knowledge has became a principal factor which will prompt the long-run economic growth. The path of exports acting on long-run economic growth is the influence of exports on technology progress. In the endogenous economic growth of Grossman and Helpman (1990), trade has introduced into this model to observe the influence of exports on endogenous economic growth. 
The result of mathematical model shows that the influencing mechanism of exports acting on technology progress is technology spillover. Exports can led technology from developed countries input into developing countries. But the exports pattern of China mainly concentrate on the processing trade, so we take suspection on the spillover effect of exports in China. Empirical study need to be carried out, in order to explore the fact. Expect for exports, the expenditure of R\&D, imports, FDI and foreign patent application are also introduced into the empirical model. The detail model is as follows:

$$
\begin{aligned}
& \operatorname{LnTFP}_{i t}=C+\alpha \operatorname{LnExport}_{i t}+\beta \operatorname{LnR} \& D_{i t}+\gamma \operatorname{Ln} \operatorname{Im} \text { port }_{i t}+\delta L n F D I_{i t} \\
& +\phi \text { LnPatent }_{i t}+\varepsilon_{i t}
\end{aligned}
$$

Among the equation, $\operatorname{TFP}_{i t}$ denotes the total factor productivity, Export ${ }_{i t}$ denotes the volume of exports, $R \& D_{i t}$ denotes the expenditure of research and development, Im port ${ }_{i t}$ denotes the volume of imports, $F D I_{i t}$ denotes the volume of foreign direct investment, Patent ${ }_{i t}$ denotes the volume of foreign patent application.

\section{(2). Data Sourcing}

The data of TFP is calculated by DEA method, the initial date of DEA comes from "China Statistical Yearbook", GDP have been converted to the price of 2002 which also comes from "China Statistical Yearbook", we use the perpetual inventory method to calculate the Provincial material capital stock. Fixed-asset investment will be converted to the price of 2002, the calculated model is as follows:

$$
K_{i t}=K_{i t-1}(1-\delta)+I_{i t}
$$

Among the above model, $I_{i 2002}$ denotes the fixed-asset investment, $K_{i t}$ denotes the physical capital stock, $K_{i t-1}$ denotes the fixed-asset investment of last year, $\delta$ denotes the rate of depreciation which will adopt the data of Jones \& Halls, $9.6 \%$.

As to 2002, the fundamental year' material capital stock, we dopt the general international research method which is invented by Halls \& Jones (1999), the estimation formula is as follows:

$$
K_{i 2002}=I_{i 2002} /\left(g_{i}+\delta_{i}\right)
$$

Among the above formula, $g_{i}$ denotes the geometric mean of the growth of fixed-asset investment. Other variables are the same as the explanation above. Data always come from "China Statistical Yearbook".

\section{(3). Empirical Study Results and Analysis}

The panel data model must copy with the selection of the random effects and fixed effect at first. Hausman test shows that this model is suitable for fixed effect. But based on the new-new trade theory, the enhance of productivity of enterprise will lead to the enterprise stride the iceberg cost to entrance international market (Melitz, 2003), so there will be a mutural effect between exports and the total factor productivity which can generate a endogeneity problem. In order to avoid the endogeneity problem, two stage least square would be introduced into this model with exports lagging phase 1 and lagging phase 2 as the instrumental variables. Hausman test result also shows that this

\begin{tabular}{|c|c|c|c|}
\hline & \multicolumn{2}{|c|}{ OLS } & \multirow{2}{*}{$\begin{array}{c}\text { 2SLS } \\
(\mathrm{j}=0)\end{array}$} \\
\hline & $(\mathrm{j}=0)$ & $(j=1)$ & \\
\hline LnExport $_{i t-j}$ & $-0.283 * * *(-2.85)$ & $-0.250^{* * *}(-2.61)$ & $-0.821 * * *(-8.25)$ \\
\hline
\end{tabular}
model exists endogeneity. After the test of instrumental variable effectiveness, exports lagging phase 1 and lagging phase 2 are effective instrumental variables. The empirical study results of OLS and 2SLS are showed as Table 1.

Table 1. The empirical results of Model 


\begin{tabular}{|c|c|c|c|}
\hline$L n R \& D_{i t}$ & $0.469 * * *(4.95)$ & $0.572 * * *(5.67)$ & $0.097 \quad(1.19)$ \\
\hline Ln Im port ${ }_{i t}$ & $(1.55)$ & $(0.29)$ & $0.676^{* * *}(7.85)$ \\
\hline $\operatorname{LnFDI}_{i t}$ & $0.340 * * *(3.44)$ & $0.324 * * *(3.24)$ & $0.352 * * *(4.36)$ \\
\hline LnPatent $_{i t}$ & $(-0.90)$ & $(-1.16)$ & $-0.209^{* *}(-2.10)$ \\
\hline$C$ & $-3.599 * * *(-5.33)$ & $-3.374 * * *(-4.40)$ & $2.651 * * *(3.84)$ \\
\hline Sargan & & & $\begin{array}{c}0.792 \\
(\mathrm{P}=0.3735)\end{array}$ \\
\hline$F$ & 58.85 & 49.27 & \\
\hline$R^{2}$ & 0.50 & 0.48 & 0.3576 \\
\hline Hausman & $74.40 * * *$ & $104.79 * * *$ & \\
\hline
\end{tabular}

Note: $* * *, * * *$ indicate $1 \%, 5 \%$ and $10 \%$ significance level respectively, the empirical study software of all is Stata12.0.

From the empirical results of Table 1, the expenditure of R\&D, imports and FDI wholly prompt the development of China's total factor productivity. Which forming a striking contrast with exports which never prompt the enhancement of China's TFP. On the contrary, when the exports rise one percent, the TFP will decline 0.283 percent. The results of lagging phase 1 exports also decline 0.25 percent and is also significant. After contral the endogeneity problem, the hinder effect of exports on TFP turn to be a further extension. We take a view that because it exists a productivity paradox within exports department. An important reality we cann't ignore is that the element intensity of exports sectors doesn't match the element endowment in China. Processing trade mainly rely on the labor, while manufacturing industry of China has turned to converge at the capital intensive. Under this circumstance, exports sectors cann't spill technology to the non-export sectors, which are going against the enhancement of technology innovation and TFP.

\subsection{The Influence of Exports on Human Capital of China}

(1). Model Specification

Since Schults (1961) put forward the theory of human capital, the role of human capital in economic growth has attracted the attention of economists. After the policy of opening and reform, the human capital benefiting from the fundamental education has prompted the economic growth of China (Fleisher \& Chen, 1997; Dmurger, 2001). The accumulation of human capital mainly through two paths: The enhancement of fundamental education; "Learning by Doing" effect which will help labor acquire work experience. Arrow (1962) introduced human capital into the economic growth model and balanced results showed that "learning by doing" effect among exports production process is the main path to prompt the standard of one country's human capital. Besides this path, Yeaple, the representative figure of new-new trade theory, takes a view that export sectors have a higher standard of human capital compared with non-export sectors, and the flow of labor between export sectors and non-export sectors will enhance the overall standard of one country's human capital (2005). Based on the analysis above, we design the empirical equation as follows:

$$
\operatorname{LnHC}_{i t}=C+\alpha \operatorname{LnEDU_{it}}+\beta \text { LnMarket }_{i t}+\gamma \operatorname{LnExport}_{i t}+\phi L n G D P_{i t}+\varepsilon_{i t}
$$

Among the above model, $H C_{i t}$ denotes the human capital variable, $E D U_{i t}$ denotes the expenditure of education, Market $_{i t}$ denotes the marketization degree which will use the proportion of state-owned enterprises labor quantities of total labor force as the measurable indicator.

(2). Data Sourcing

As to the data of provincial human capital, Li (2010) use Jorgenson-Fraumeni's method of lifetime income to 
calculate the human capital of every province. We adopt Li's data. The expenditure of education comes from "China Statistical Yearbook", the labor number of state-owned enterprises and total labor force number also come from "China Statistical Yearbook".

(3). The empirical results and analysis

After the Hausman test, result shows that the fixed effect is suitable for the model. In order to avoid the endogeneity problem, we chose the exports lagging phase 1 and lagging phase 2 as instrumental variables. The empirical study of OLS and 2SLS are exhibited on Table 2 as follows:

Table 2. The empirical study of OLS and 2SLS

\begin{tabular}{|c|c|c|c|}
\hline \multirow[b]{3}{*}{$\operatorname{LnExport}_{i t-j}$} & \multicolumn{2}{|c|}{ OLS } & \multirow{3}{*}{$\begin{array}{c}\text { 2SLS } \\
(\mathrm{j}=0) \\
0.047^{* * *}(3.31)\end{array}$} \\
\hline & \multirow{2}{*}{$\begin{array}{c}(\mathrm{j}=0) \\
0.062 * * *(3.13)\end{array}$} & $(j=1)$ & \\
\hline & & $0.022 \quad(1.08)$ & \\
\hline$L n E D U_{i t}$ & $-0.139^{* * *}(-2.75)$ & $-0.142 * * *(-2.75)$ & $0.049 * \quad(1.81)$ \\
\hline LnMarket $_{i t}$ & $0.199 * *(2.17)$ & $0.305^{* * *}(2.97)$ & $0.267 * * *(4.00)$ \\
\hline$L n G D P_{i t}$ & $0.421 * * *(6.22)$ & $0.448^{* * *}(6.54)$ & $1.149 * * *(25.33)$ \\
\hline C & $11.199 * * *(28.53)$ & $11.813^{* * *}(29.32)$ & $1.990 * *(3.14)$ \\
\hline Sargan & & & $\begin{array}{c}0.255 \\
(\mathrm{P}=0.6135)\end{array}$ \\
\hline Time fixed effect & & & Yes \\
\hline District fixed effect & & & Yes \\
\hline$F$ & 277.44 & 182.30 & \\
\hline$R^{2}$ & 0.79 & 0.73 & \\
\hline Hausman & $38.67 * * *$ & $36.78 * * *$ & \\
\hline
\end{tabular}

Note: $* * *, * * *$ indicate $1 \%, 5 \%$ and $10 \%$ significance level respectively, the empirical study software of all is Stata12.0.

Empirical study shows that exports significantly promote the improvement of the level of human capital in China. When exports rise one percent, the human capital will improve $0.062 \%$. The degree of labor marketization and the standard of GDP significantly promote the enhancement of human capital. On the contrary, the expenditure of education doesn't prompt the standard of human capital. 2SLS results also support the view that exports promote the standard of human capital, meanwhile, 2SLS results have showed that education expenditure turn to be positive to human capital.

\subsection{The Influence of Exports on Consumption of Energy and Mineral Resources}

\section{(1). Model Specification}

The potential economic growth depends on the amount of natural resources within one country. It's will to be apparent that when two economic entities have the same technology standard and human capital level, the long-run economic growth will depend on the supply of energy and mineral resources. A typical example of energy supply shortages which limited the long-run economic growth is the 1970s when OPEC's production restriction. This affair makes the United States and Europe sank into the mire of economic growth. After the policy of opening and reform, China has been consuming enormous energy and mineral resources on exports production which limite the natural resources China will use in the future. To move forward a single step, exports of China's model will decrease the potential of long-run economic growth. In order to research the effect accurately, we constitute the empirical model as follows: 


$$
\operatorname{LnP}_{i t}=C+\alpha \operatorname{LnExport}_{i t}+\beta \text { LnInvest }_{i t}+\gamma \text { LnMoney }_{i t}+\phi \operatorname{LnGDP}_{i t}+\varepsilon_{i t}
$$

Among the above model, $P_{i t}$ denotes the rising rate of agriculture oil price, Invest ${ }_{i t}$ denotes the amount of investment, Money ${ }_{i t}$ denotes the amount of money launched on the market.

\section{(2). Data Sourcing}

The degree of natural resources scarcity could be reflected by the price of energy and mineral resources, so we use the price of agriculture oil which could be found on the statistical yearbook to represent the scarcity degree of factor endowment (Note 1). The amount of money launched on the market and investment amount all come from "Chinese Statistical Yearbook".

(3). The Empirical Results and Analysis

Hausman test shows that this model should be suitable for the fixed effect model, the detail empirical results are expressed on Table 3 as follows:

Table 3. The Empirical results of Model 3

\begin{tabular}{ccc}
\hline & \multicolumn{3}{c}{ Model 3} \\
\cline { 2 - 3 } & $0.061^{* * *}(4.46)$ & $(\mathrm{j}=1)$ \\
\hline LnExport $_{i t-j}$ & & $0.047^{* * *}(3.36)$ \\
LnInvest $_{i t}$ & $-0.052^{* *}(-2.02)$ & $-0.058^{* *}(-2.10)$ \\
LnMoney $_{i t}$ & $0.138^{* * *}(2.98)$ & $0.055 \quad(1.14)$ \\
LnGDP $_{i t}$ & & $0.421^{* * *}(7.22)$ \\
$C$ & $0.325^{* * *}(5.57)$ & $0.446^{*} \quad(1.84)$ \\
$F$ & $-0.040 \quad(0.865)$ & 893.45 \\
$R^{2}$ & 1138.47 & 0.9307 \\
Hausman & 0.939 & $67.31^{* * *}$ \\
\hline
\end{tabular}

Note: $* * * * *, *$ indicate $1 \%, 5 \%$ and $10 \%$ significance level respectively, the empirical study software of all is Stata12.0.

Resluts show that exports prompt the rising of energy and mineral resource price, and when exports rise one percent, energy price will rise $0.061 \%$, meanwhile exports lagging phase 1 rise one percent, energy price will rise $0.047 \%$. The amount of Money and GDP also prompt the rising of energy price. Form a striking contrast, The investment never prompts the rising of energy and mineral resource price, on the contrary, investment decreases the price of energy. So we take the view to explain this phenomenon that the investment mainly concentrates on physical capital and infrastructure which decrease the transportation cost.

After the empirical study on the influence of exports on TFP, human capital and price of energy and mineral resources. In order to check the whole effect of exports on long-run economic growth, we need to calculate the contribution degree of every aspect which could influence the long-run economic growth. The next part will apply empirical study focusing on this problem. 


\section{The Contribution Degree of Every Aspect on Long-run Economic Growth}

\subsection{Model Specification}

The influence of exports on TFP, human capital and price of energy and mineral resources must focus on the long-run economic growth. In order to calculate the contribution degree of TFP, human capital and price of energy and mineral resources, we adopt the Cobb-Douglas production function to implement empirical study as follows:

$$
G D P_{i t}=T F P_{i t}^{\lambda} * H C_{i t}^{\alpha} * L_{i t}{ }^{\beta} * K_{i t}^{\gamma} * P_{i t}^{\delta}
$$

To facilitate the econometric analysis, Model turn to be the Ln form as follows:

$$
L n G D P_{i t}=C+\lambda L n T F P_{i t}+\alpha L n H C_{i t}++\beta L n L_{i t}+\gamma \operatorname{LnK} K_{i t}+\delta L n P_{i t}+\varepsilon_{i t}
$$

Among this model, the meaning of variables is as introduction above, and the data sourcing also come from the place we have introducted above.

\subsection{Empirical Results and Analysis}

Hausman test shows that this model should be suitable for the fixed effect model, the detail empirical results are expressed on Table 4 as follows:

\begin{tabular}{|c|c|}
\hline $\operatorname{LnTFP}_{i t}$ & $0.060^{* * *}(6.41)$ \\
\hline$L n H C_{i t}$ & $0.473 * * *(18.14)$ \\
\hline$L n L_{i t}$ & $0.388^{* * *}(20.25)$ \\
\hline $\operatorname{Ln} K_{i t}$ & $0.681 * * *(35.83)$ \\
\hline $\operatorname{Ln} P_{i t}$ & $0.051^{* * *}(6.61)$ \\
\hline$C$ & $-6.000 * * *(-22.79)$ \\
\hline$F$ & 5181.81 \\
\hline$R^{2}$ & 0.9875 \\
\hline Hausman & $85.86^{* * *}$ \\
\hline
\end{tabular}

Table 4. Empirical results of Model

Note: $* * *, * *, *$ indicate $1 \%, 5 \%$ and $10 \%$ significance level respectively, the empirical study software of all is Stata12.0.

The empirical study shows that human capital, the amount of labor and physical capital are all important factors which will prompt the long-run economic growth in China. This period the power relied by the economic growth in China mainly on the Labor and the physical capital. But what make we feel confused is that the rising of energy price prompt the economic growth in China which could be explained by the reality that energy sectors are controlled by state-owned enterprises. The commodity price of monopolistic department couldn't reflect the real relationship between demand and supply which led to the resluts differential from our expection. TFP prompt the economic growth in China, but the degree is less then our expection. We take a view that the economic growth model of China mainly rely on the input of production factors, rather than technology progress.

\section{Conclusion and Policy Suggestion}

Based on the theoretical analysis and empirical study results above, we need tabulate this conclusion on one table. 
Table 5. The Summarized results of the influence of exports on long-run economic growth

\begin{tabular}{|c|c|c|c|}
\hline & \multicolumn{3}{|c|}{ The elasticity of every variable when exports rise one percent } \\
\hline & $T F P$ & $H C$ & $P$ \\
\hline \multicolumn{4}{|l|}{ Variables } \\
\hline \multirow[t]{2}{*}{ Elastic coefficient } & $-0.821 \%$ & $0.047 \%$ & $0.061 \%$ \\
\hline & \multicolumn{3}{|c|}{ The elasticity of GDP when every variable rise one percent } \\
\hline Variables & $T F P$ & $H C$ & $P$ \\
\hline Elastic coefficient & $0.060 \%$ & $0.403 \%$ & $0.051 \%$ \\
\hline \multirow{2}{*}{$\begin{array}{l}\text { The influence coefficient of } \\
\text { exports on GDP through three } \\
\text { paths }\end{array}$} & $-0.821 * 0.060 \%$ & $0.047 * 0.403 \%$ & $0.061 * 0.051 \%$ \\
\hline & $=-0.049 \%$ & $=0.019 \%$ & $=0.003 \%$ \\
\hline $\begin{array}{l}\text { Sum of elasticticy on GDP when } \\
\text { exports rise one percent }\end{array}$ & \multicolumn{3}{|c|}{$-0.049 \%+0.019 \%+0.003 \%=-0.027 \%$} \\
\hline
\end{tabular}

According to the summarized results of Table 5, when the exports of China rise one percent, the long-run economic growth will decrease $0.027 \%$. Our results indeed are conservative, because the energy market is monopoly which cann't reflect the real price formed by the supply and demand. Of course, the research path of the influence of exports on long-run economic growth never covers all paths, such as the regime aspect. Acemoglu et al. (2005) took deep research about the role of regime on European long-run economic growth in 16th century. Export trade strengthened the power of merchants which induced capitalist revolution. Subsequently, concrete institutions which aim at protecting the interests of the bourgeoisie prompted the long-run economic growth. As to the regime of China, subject to the characteristics of transition economies, so changing institutional environment lead us cann't capture the measurement of regime.

The negative effect of exports on long-run economic growth in China could be explained by the deviation between production structure and exports structure. On the one hand, the production structure gradually converges to the hige-tech industries. On the other hand, the export sectors are still stuck in the processing trade which fixed China's economic growth model. Within the global value chain devision, China undertake the new World Factory role which overdraft enormous production factors. Under the circumstance that rising production factor price and scarce natural resources, China has lost the foundation of processing trade.

If China wants to reverse this negative influence of exports on long-run economic growth, the first task is to transform the exports structure, and decrease the proportion of processing trade. Exports has finished the aim that realizing the accumulation of foreign exchange reverse. The capital also become flush and technology has acquired a great degree progress which all support the event that China has the condition to transform the exports structure. China's exports structure should transform to the high-tech sectors which will be sustained by physical capital updates and technology innovation. Meanwhile, The domestic factor market also needs reform and the marketization degree should also be improved while will lead the price of labor, land, energy and other essential production factors to be formed by balance of supply and demand. Reducing the factor price distortion is still the reform direction of China which will reflect the real production cost of export commodity.

\section{References}

Abu-Qarn, A.S., \& Suleiman, A. (2001). Export-led Growth: Empirical Evidence from the Mena Region. Ben Gurion University Monaster Center for Economic Research, 1-34.

Acemoglu, D., Johnson, S., \& Robinson, J. (2005). The Rise of Europe: Atlantic Trade, Institutional Change, and Economic Growth. The American Economic Review, 95(3), 546-579. https://doi.org/10.1257/0002828054201305

Aghion, P., \& Howitt, P. (1992). A Model of Growth through Creative Destruction. Econometrica, 60(2), 323-351. https://doi.org/10.2307/2951599 
Ahmad, J., \& Kwan, A.C.C. (1991). Causality between Exports and Economic Growth: Empirical Evidence form Africa. Economics Letters, 37(3), 243-248. https://doi.org/10.1016/0165-1765(91)90218-A

Akbar, M., \& Fatima, Z. (2003). Are Exports an Engine of Growth in Pakistan?. Ecomod 2003 International Conference, Istanbul, pp.1-35.

Alam, M.I. (2003). Manufactured Exports, Capital Good Imports, and Economic Growth: Experience of Mexico and Brazil. International Economic Journal, 17(4), 85-105. https://doi.org/10.1080/10168730300080028

Arrow, K.J. (1962). The Economic Implications of Learning by Doing. Review of Economic Studies, 29(80), 73-155. https://doi.org/10.2307/2295952

Badinger, H., \& Tondl, G. (2002). Trade, Human Capital and Innovation: the Engines of European Regional Growth in the 1990s. Institute for European Affairs, pp.1-34.

Becker, G. (1964). Human Capital (2nd ed.). Columbia University Press, New York.

Boltho, A. (1996). Was Japanese Growth Export-led?. Oxford Economic Papers, New Series, 48(3), 415-432. https://doi.org/10.1093/oxfordjournals.oep.a028576

Cairncross, A.K. (1961). International Trade and Economic Development. Economica, 28(111), 235-251. https://doi.org/10.2307/2601600

Chow, P.C.Y. (1987). Causality between Export Growth and Industrial Development: Empirical Evidence from NICs. Journal of Development Economics, 26(1), 55-63. https://doi.org/10.1016/0304-3878(87)90051-4

Chuang, Y.C. (1998). Learning by Doing, the Technology Gap and Growth. International Economic Review, 39(3), 697-721. https://doi.org/10.2307/2527396

Chuang, Y.C. (2002). The Trade-Induced Learning Effect on Growth: Cross-Country Evidence. Journal of Development Studies, 39(2), 137-154.

Cuaresma, J.C., \& Worz, J. (2005). On Export Composition and Growth. Review of World Economics, 141(1), 33-49. https://doi.org/10.1007/s10290-005-0014-z

Dmurger, S. (2001). Infrastructure Development and Economic Growth: An Explanation for Regional Disparities in China?. Journal of Comparative Economics, 19, 95-117. https://doi.org/10.1006/jcec.2000.1693

Dodaro, S. (1993). Exports and Growth: A Reconsideration of Causality. The Journal of Developing Areas, 27(2), 227-244.

Feder, G. (1982). On Export and Economic Growth. Journal of Development Economics, 12, 59-73. https://doi.org/10.1016/0304-3878(83)90031-7

Fleisher, B., \& Chen, J. (1997). The Coast-Noncoast Income Gap, Productivity and Regional Inequality in China. Journal of Development Economics, 92(2), 215-231. https://doi.org/10.1016/j.jdeveco.2009.01.010

Frankel, J.A., \& Romer, D. (1999). Does Trade Cause Growth?. The American Economic Review, 89(3), 379-399. https://doi.org/10.1257/aer.89.3.379

Ghatak, S., \& Price, S.W. (1997). Export, Composition and Economic Growth: Cointegration and Causality Evidence for India. Weltwirtschaftliches Archiv, 133(3), 538-553. https://doi.org/10.1007/BF02707502

Grossman, G.M., \& Helpman, E. (1990). Trade, Knowledge Spillovers and Growth. NBER Working Paper Series, 1-15. https://doi.org/10.3386/w3485

Grossman, G.M., \& Helpman, E. (1991). Quality Ladders in the Theory of Growth. Review of Economics Studies, 58(1), 43-61. https://doi.org/10.2307/2298044

Hall, R.E., \& Jones, C.I. (1999). Why Do Some Countries Produce So Much More Output Per Worker than Others. The Quarterly Journal of Economics, 114(1), 83-116. https://doi.org/10.1162/003355399555954

Herzer, D., Lehmann, F.N., \& Siliverstovs, B. (2005). Export-led Growth in Chile: Assessing the Role of Export Composition in Productivity Growth. America Institute for Economic Research, Germany, 1-30.

Howitt, P., \& Aghion, P. (1998). Capital Accumulation and Innovation as Complementary Factors in Long-Run Growth. Journal of Economic Growth, 3(2), 111-130. https://doi.org/10.1023/A:1009769717601

Jung, W.S., \& Marshall, D.J. (1985). Exports, Growth and Causality in Developing Countries. Journal of Development Economics, 18(1), 1-12. https://doi.org/10.1016/0304-3878(85)90002-1 
Kaushik, K.K., Arbenser, L.N., \& Klein, K.K. (2008). Export Growth, Export Instability, Investment and Economic Growth in India: A Time Series Analysis. The Journal of Developing Areas, 41(2), 155-170. https://doi.org/10.1353/jda.2008.0018

Keong, C.C., Yusop, Z., \& Sen, V.L.K. (2005). Export-led Growth Hypothesis in Malaysia: An Investigation Using Bounds Test. Sunway Academic Journal, 2, 13-22.

Kilavuz, E., \& Topcu, B.A. (2012). Export and Economic Growth in the Case of the Manufacturing Industry: Panel Data Analysis of Developing Countries. International Journal of Economics and Financial Issues, 2(2), 201-215.

Lim, S.Y., Ghazali, M.F., \& Ho, C.M. (2011). Export and Economic Growth in Southeast Asia Current Newly Industrialized Countries: Evidence from Nonparametric Approach. Economics Bulletin, 31(3), 2683-2693.

Lucas, R.E. (1988). On the Mechanics of Economic Development. Journal of Monetary Economics, 22, 3-42. https://doi.org/10.1016/0304-3932(88)90168-7

Medina-Smith, E.J. (2001). Is the Export-led Growth Hypothesis Valid for Developing Countries? A Case Study of Costa Rica. United Nations Conference on Trade and Development. Policy Issues in International Trade and Commodities Study Series, 7, 1-57.

Melitz, M.J. (2003). The Impact of Trade on Intra-industry Reallocations and Aggregate Industry Productivity. Econometrica, 71(6), 1695-1725. https://doi.org/10.1111/1468-0262.00467

Oxley, L. (1993). Cointegration, Causality and Export-led Growth in Portugal, 1865-1985. Economics Letters, 43(2), 163-166. https://doi.org/10.1016/0165-1765(93)90030-G

Parida, P.C., \& Sahoo, P. (2007). Export-led Growth in South Asia: A Panel Cointegration Analysis. International Economic Journal, 21(2), 155-175. https://doi.org/10.1080/10168730701345414

Ram, R. (1985). Exports and Economic Growth: Some Additional Evidence. Economic Development and Cultural Change, 33(2), 415-425. https://doi.org/10.1086/451468

Ram, R. (1987). Exports and Economic Growth in Developing Countries: Evidence from Time-Series and Cross-Section Data. Economic Development and Cultural Change, 36(1), 51-63. https://doi.org/10.1086/451636

Rivera-Batiz, L.A., \& Romer, P.M. (1991). Economic Integration and Endogenous Growth. The Quarterly Journal of Economics, 106(2), 531-555. https://doi.org/10.2307/2937946

Romer, P.M. (1990). Endogenous Technological Change. Journal of Political Economy, 98(5), S71-S102. https://doi.org/10.1086/261725

Schultz, T. (1961). Investment in Human Capital. American Economic Review, 51(1), 1-17.

Stiglitz, J.E, (2007). Making Globalization Work for Developing Countries. W. W. Norton and Company. Inc.

Tyler, W.G. (1980). Growth and Export Expansion in Developing Countries: Some Empirical Evidence. Journal of Development Economics, 9(2), 121-130.

Yeaple, S. (2005). A Simple Model of Firm Heterogeneity, International Trade and Wages. Journal of International Economics, 65, 1-120. https://doi.org/10.1016/j.jinteco.2004.01.001

Young, A. (1991). Learning by Doing: the Dynamic Effects of International Trade. The Quarterly Journal of Economics, 106(2), 369-405. https://doi.org/10.2307/2937942

\section{Note}

Note 1. $P_{i t}=P_{i 2002} * \prod_{t=2003}^{t} I_{n d e x_{i t}}$, among this equation, we set $P_{i 2002}=1$, Index $x_{i t}$ represents the price index of agricultural oil price index which comes from "Chinese Statistical Yearbook". 